\title{
Tissue effect on RNA:DNA ratios of marine fish larvae
}

\author{
M. PILAR OLIVAR ${ }^{1}$, MARINA V. DIAZ ${ }^{2}$ and M. ALEXANDRA CHÍCHARO ${ }^{3}$ \\ ${ }^{1}$ Institut de Ciències del Mar - CSIC, Passeig Marítim 37-49, Barcelona 08003, Spain. E-mail: polivar@icm.csic.es \\ 2 Instituto Nacional de Investigación y Desarrollo Pesquero, Paseo Victoria Ocampo 1, \\ B7602HSA Mar del Plata, Argentina. \\ ${ }^{3}$ Centre of Marine Sciences, University of Algarve, Campus de Gambelas, 8000-117 Faro, Portugal.
}

\begin{abstract}
SUMMARY: In some routine studies of larval condition based on RNA:DNA ratios, heads and/or guts are removed for further age and feeding analysis. Also, during capture larvae are often found with their eyes missing. In this work we analysed tissues effects (muscle, head, eye, gut and the whole larvae) on RNA:DNA ratios from different species (Sardina pilchardus, Engraulis encrasicolus, Atherina presbyter and Paralichthys orbignyanus) in different developmental stages and from different locations. For all species and development phases, it was shown that RNA:DNA ratios in the head were significantly lower than in muscle or gut. The comparison of RNA:DNA ratios of head with or without eyes did not show significant differences. In a comparison of results from muscle from two tail sections, RNA:DNA ratios were higher for the anterior section in Sardina pilchardus and Engraulis encrasicolus larvae. Caution is needed when RNA:DNA ratios are compared with other studies employing different dissection protocols. For the species studied we propose conversion factors to be applied to RNA:DNA ratio data when different body sections are analysed. We discuss the most appropriate tissues for assessing nutritional condition in fish larvae, based on trends in concentrations of nucleic acids and ratios during starvation experiments.
\end{abstract}

Keywords: RNA:DNA, tissues, starvation, condition, Sardina pilchardus, Engraulis encrasicolus, Atherina presbyter, Paralichthys orbignyanus.

RESUMEN: EFECTO DEL TIPO DE TEJIDO SOBRE LOS COCIENTES ARN:ADN EN LARVAS DE PECES MARINOS. - En estudios de condición nutricional larvaria basados en la relación ARN:ADN, las cabezas y/o tubos digestivos suelen diseccionarse para posteriores estudios de edad o alimentación. Además, durante la captura algunas larvas pierden los ojos. En este trabajo analizamos el efecto de diferentes tejidos (músculo, cabeza, ojos y tubo digestivo) sobre la relación ARN:ADN en Sardina pilchardus, Engraulis encrasicolus, Atherina presbyter y Paralichthys orbignyanus, en diferentes estadios de desarrollo y en diversas regiones. En todas las especies la relación ARN:ADN en la cabeza fue significativamente menor que para el músculo o el tubo digestivo. La comparación de la relación ARN:ADN de la cabeza con o sin ojos no mostró diferencias significativas. Al comparar dos secciones de músculo de la cola en Sardina pilchardus y Engraulis encrasicolus se observó mayor ARN:ADN en la parte anterior que en la posterior. Es necesaria precaución cuando se comparan ARN:ADN entre estudios que emplean diferentes protocolos de disección. Proponemos factores de conversión para ser aplicados a las relaciones ARN:ADN cuando se analizan diferentes secciones del cuerpo. Se discute cuales son los tejidos más apropiados para determinar la condición nutricional de larvas de peces, basados en las concentraciones de ácidos nucleicos y sus cocientes obtenidos en experimentos de inanición.

Palabras clave: ARN:ADN, tejidos, inanición, condición, Sardina pilchardus, Engraulis encrasicolus, Atherina presbyter, Paralichthys orbignyanus.

\section{INTRODUCTION}

Condition indices have been widely used to assess the importance of starvation in fish larvae (e.g. O’Connell, 1980; Buckley, 1984; Theilacker,
1986; Clemmesen, 1994). Many studies have shown evidence that the RNA:DNA ratio is one of the best indicators of the nutritional condition and growth of several marine organisms (e.g. Clemmesen, 1994; Bailey et al., 1995; Folkvord et al., 1996) and, to 
date, it is the most widely used biochemical index for determining larval condition. It is an eco-physiological index that gives a measure of the synthetic capacity of the cell and usually correlates with nutritional status (Ferron and Leggett, 1994; Buckley et al., 1999). This index is based on the assumption that the amount of DNA, the primary carrier of genetic information, is stable under changing environmental situations within the somatic cells of a species, whereas the amount of RNA, directly involved in protein synthesis, is known to vary with age, lifestage, organism size, disease state and changing environmental conditions (Bulow, 1970). Thus, organisms in good condition tend to have higher RNA:DNA ratios than those in poor condition (e.g. Robinson and Ware, 1988; Clemmesen, 1994). In fact RNA:DNA ratios have been used on a wide range of marine organisms, mainly plankton, phytoplankton (Berdalet and Dortch, 1991), zooplankton (e.g. Ikeda et al., 2007); larval fish (e.g. Buckley, 1984; Caldarone and Buckley, 1991; Clemmesen, 1994; Ramírez et al., 2001), juvenile and adult fish (e.g. Goolish et al., 1984), bivalves (e.g. Grémare and Vétion, 1994), cephalopods (e.g. Sykes et al., 2004) and shrimps (e.g. Chícharo et al., 2007). They have shown to reflect the nutritional status and may be useful in monitoring their physiological state in the field.

Many studies have now demonstrated a close link between energy metabolism, metabolic rate and food availability for fishes. In fact, changes in protein synthesis directly correlate with RNA:DNA, although this pattern depends on tissue type and the extent of laboratory treatment (Lowery and Somero, 1990; Houlihan et al., 1986).

Some studies have advocated caution in the use of RNA:DNA ratios on the basis of the lack of sensitivity of some techniques (Grémare and Vétion, 1994) and the influence of the analytical protocol and standard used (Berdalet et al., 2005; Caldarone et al., 2006). It has also been pointed out that the RNA:DNA ratio may be correlated with age, size or developmental stage (Clemmesen, 1994; Suthers et al., 1996; Rooker and Holt, 1996; Bergeron, 1997), and that is influenced by temperature (Buckley et al., 2008) and diel cycle (Rooker and Holt, 1996; Chícharo et al., 1998). However, the effect of tissue on RNA:DNA ratios in larval fish has not been analysed. In some routine studies of larval condition based on RNA:DNA ratios, heads and/or guts are removed for further age and feeding analysis.
Also, during capture larvae are often found with their eyes missing. This raised the question of whether certain tissues differ in RNA:DNA ratios due to their metabolic differences during ontogenetic development.

In this work we aimed to assess tissue effects (muscle, head, eye, gut and the whole larvae) on RNA:DNA ratios from different species (Sardina pilchardus, Engraulis encrasicolus, Atherina presbyter and Paralichthys orbignyanus), in different developmental stages (pre-flexion, flexion and post-flexion), from different locations (northwestern Mediterranean, northeastern Atlantic and southwestern Atlantic) and at several water temperatures $\left(14-25^{\circ} \mathrm{C}\right)$.

\section{MATERIALS AND METHODS}

\section{Larval source}

All sampled larvae were placed on ice and immediately stored frozen in liquid nitrogen. The sorting procedure lasted less than ten minutes. In the laboratory, larvae were thawed, identified, measured (to the nearest $0.1 \mathrm{~mm}$ ) under a dissecting microscope equipped with an ocular micrometer and classified according to developmental stage as pre-flexion, flexion and post-flexion larvae. Pre-flexion and flexion larvae were grouped as early stages for statistical analysis. Detailed sampling schemes are shown in Table 1. After tissue selection (gut, eyes, head, muscle), the different body parts were freeze-dried and stored at $-80^{\circ} \mathrm{C}$ until analyses were carried out. All procedures took place on ice.

Sardina pilchardus, Engraulis encrasicolus and Atherina presbyter were captured at sea and Paralichthys orbignyanus larvae were reared in the laboratory. In the northeastern Atlantic (South Portuguese coast) Sardina pilchardus and Atherina presbyter larvae were collected with a light trap composed of an acrylic pipe of $25 \mathrm{~cm}$ diameter and $50 \mathrm{~cm}$ height. The base of the trap was a PVC box where the light was fixed. Engraulis encrasicolus and Sardina pilchardus larvae from the northwestern Mediterranean were collected by means of oblique Bongo hauls from $c a .100 \mathrm{~m}$ to the surface. The cod end of one of the nets was retrieved without previous washing of the net in order to avoid damaging the larvae, which were immediately sorted out and frozen in liquid nitrogen until arrival at the laboratory, where they were transferred to a deep-freezer $\left(-80^{\circ} \mathrm{C}\right)$. 
TABLE 1. - General information about sampling and experimental conditions for the studied species (H- head, M- muscle, E-eye, G-gut).

\begin{tabular}{|c|c|c|c|c|}
\hline & Sardina pilchardus & Engraulis encrasicolus & Atherina presbyter & Paralichthys orbignyanusç \\
\hline Temperature & $14-17^{\circ} \mathrm{C}$ & $23-25^{\circ} \mathrm{C}$ & $14^{\circ} \mathrm{C}$ & $20^{\circ} \mathrm{C}$ \\
\hline Geographical area & North Atlantic & Northwestern Mediterranean & North Atlantic & South Atlantic \\
\hline Feeding conditions & Natural & Natural & Natural & Fed, Starved \\
\hline Stages & $\begin{array}{l}\text { Pre-flexion } \\
\text { Flexion } \\
\text { Post-flexion }\end{array}$ & $\begin{array}{c}\text { Flexion } \\
\text { Post-flexion }\end{array}$ & Post-flexion & $\begin{array}{l}\text { Pre-flexion } \\
\text { Post-flexion }\end{array}$ \\
\hline Sampler & Light trap & Bongo & Light trap & Direct \\
\hline Standard length & 7.1-30.8 mm & $5.7-18.1 \mathrm{~mm}$ & $7-20.4 \mathrm{~mm}$ & $5.6-7.5 \mathrm{~mm}$ \\
\hline Tissues analysed & $\mathrm{H}, \mathrm{M}, \mathrm{E}, \mathrm{G}$ & $\mathrm{H}, \mathrm{M}, \mathrm{G}$ & $\mathrm{H}, \mathrm{M}, \mathrm{E}, \mathrm{G}$ & $\mathrm{H}, \mathrm{M}, \mathrm{G}$ \\
\hline
\end{tabular}

Paralichthys orbignyanus larvae were reared at $20^{\circ} \mathrm{C}$ at densities of 20 individuals per litre and were fed with algae (Nannochloropsis oculata) and rotifers (Brachionus plicatilis). Larvae were randomly assigned to two feeding treatments: fed and completely starved. Pre-flexion larvae of both feeding treatments were sampled 19 days after hatching (DAH) for nucleic acid analyses. A second experiment was carried out, and between the 25th and 28th DAH another group of larvae, which were fed and deprived of food, were sampled to test the effect of food deprivation on the several tissues in postflexion stages.

Larvae were sampled daily from each treatment, measured and dissected on ice, and immediately stored at $-80^{\circ} \mathrm{C}$ until the analyses were carried out.

\section{Dissection method}

In all species studied, the head was separated from the rest of the body by means of a scalpel by cutting the larvae along the cleithrum. Then the gut (including the adjacent organs, liver and pancreas) was separated from the rest of the tail. Eyes were easily removed using the same scalpel. In some specimens of Sardina pilchardus, Engraulis encrasicolus and Paralichthys orbignyanus, the tail was divided into two approximately equidistant anterior and posterior sections. The dissection procedure was performed on ice. Individual body sections were placed into individual vials for the next freeze-drying process, which lasted for $c a .18 \mathrm{~h}$ at $-110^{\circ} \mathrm{C}$. All sections of fish larvae were weighed on an ultra balance with a precision of $1 \mu \mathrm{g}$ (Mettler Toledo MX5).

Nucleic acid concentrations were reported individually for eyes, head, muscle and gut. The head included the eyes. The anterior part of tail muscle was reported as Muscle 1 and the posterior part as Muscle 2. Body was defined as head plus muscle and whole body as head, muscle and gut.

\section{Analytical protocol}

The analytical procedure was adapted from the methodology presented by Caldarone et al. (2001) and Caldarone (2005) for fish larvae, with the main modification related to the use of $1 \mathrm{ml}$ of assay sample instead of microplate. The protocol involves mechanical and chemical homogenization of tissues and subsequent fluorescence-photometric measurements using ethidium bromide (EB) as a specific nucleic acid fluorochrome dye. Thawed larvae were immersed in a solution containing Tris EDTA and sarcosil (sodium $N$-lauroylsarcosine) and homogenised by means of mechanical shaking for 5 minutes in a shaking mill with different size glass beads. Subsequently, the vials were transferred to a vortex for 30 minutes. The samples were then centrifuged for 15 minutes at $12000 \mathrm{rpm}$ and $2^{\circ} \mathrm{C}$. The concentration of sarcosil for digestion was $0.5 \%$ and the final concentration in the reading cuvette was $0.05 \%$.

Fluorescence was measured on a spectrofluorometer (Bowman) at an excitation wavelength of 360 $\mathrm{nm}$ and an emission wavelength of $590 \mathrm{~nm}$. Special attention was paid to maintain constant room and spectrophotometer temperature during the reading process. A re-circulating refrigeration bath was adapted to the spectrofluorometer to maintain constant temperature. We measured endogenous fluorescence (before EB addition) from the first set of samples for each tissue, which was negligible, so it was not considered in the calculations of nucleic acids concentrations. Total fluorescence was first read, and then samples were incubated with ribonuclease 
A (Type-II A) at $37^{\circ} \mathrm{C}$ for 20 minutes, and cooled to room temperature before reading.

The fluorescence due to total RNA, mainly ribosomal, was calculated as the difference between total fluorescence (RNA and DNA) and the fluorescence measured after ribonuclease treatment, which is assumed to be due to DNA. Since we followed a standard protocol based on the use of EB and detergent (Belchier et al., 2004; Caldarone et al., 2001; Caldarone et al., 2006), which has been previously used in some similar species and stages, we assume that residual fluorescence was insignificant and did not add DNase. Concentrations were determined by running standard curves of DNA-EB and RNA-EB every day with known concentrations of DNA and RNA (Calf Thymus DNA ultrapure and 18S+28S Ribosomal RNA from Calf Liver, from SIGMA) in the appropriate range of concentrations. The results were expressed as $\mu \mathrm{g} \mathrm{DNA} / \mathrm{mg} \mathrm{DW}, \mu \mathrm{g} \mathrm{RNA} / \mathrm{mg}$ DW and RNA/DNA. The average ratio of DNA and RNA slopes was $4.86 \pm 0.39$.

\section{Statistical analysis}

Differences among tissues were determined by $t$ test (2 groups) or ANOVA (more than 3 groups) followed by Tukey's honestly significant difference (HSD) test.

\section{RESULTS}

The pattern of variation in RNA:DNA values in the head, muscle, gut, body (head and muscle) and whole body (head, muscle and gut) obtained by combining data from the four studied species showed significant differences among tissues $(p<0.001)$ (Fig. 1 and Table 2), with the lowest ratios for the head region and the highest for the gut. As a consequence, when head and muscle tissues (body), or head, muscle and gut (whole body) were considered together, the RNA:DNA obtained had roughly intermediate values. The post-hoc Tukey test indicated that head, muscle and gut differ from each other and also from body or whole body, while body and whole body were not significantly different from each other. Individual ANOVAs for each species, i.e. Sardina pilchardus, Engraulis encrasicolus, Atherina presbyter and Paralichthys orbignyanus, showed similar patterns, with significant differences among tissues (Table 3) and with the lowest ratios
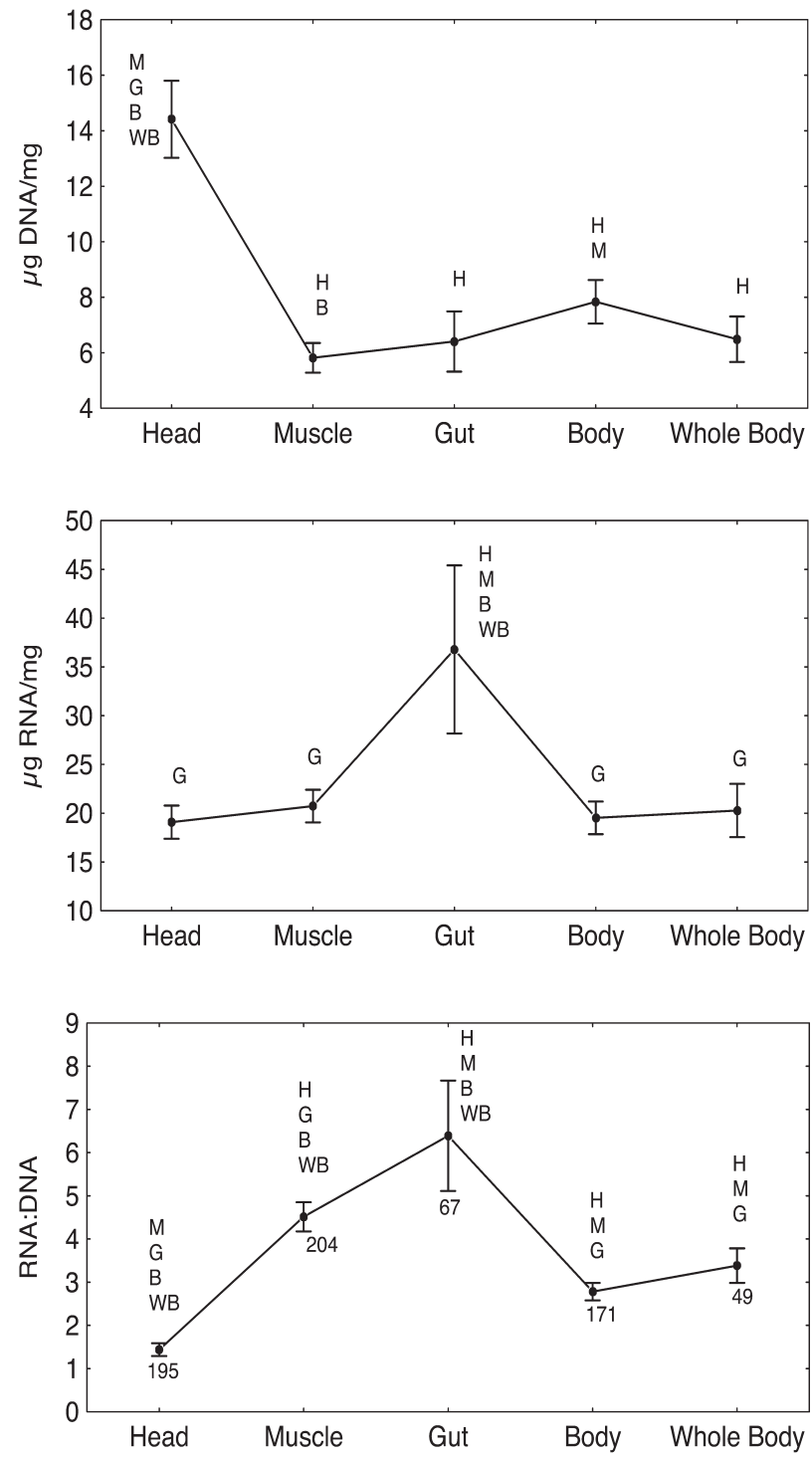

FIG. 1. - Mean values and 95\% confidence intervals of DNA and RNA content $(\mu \mathrm{g} / \mathrm{mg} \mathrm{DW})$ and RNA:DNA ratios in the head, muscle, gut, body and whole body tissues for the grouped studied species. Different letters indicate significant differences $(\mathrm{p}<0.001)$ among tissues, after one-way ANOVA followed by post-hoc Tukey's (HSD) test. Number of samples indicated below each point. H: Head. M: Muscle. G: Gut. B: Body (Head+Muscle). WB: Whole Body (Head+Muscle+Gut)

TABLE 2. - Summary of the results of the one-way analysis of variance (ANOVA) for all the grouped studied species (Sardina pilchardus, Engraulis encrasicolus, Atherina presbyter and Paralichthys orbignyanus), showing the significance of the factors (tissues). DF: degrees of freedom and MS: mean square.

\begin{tabular}{lcccc}
\hline & DF & MS & F & p \\
\hline RNA/DNA & 4 & 413.4 & 78.2 & $<0.001$ \\
Error & 676 & 5.3 & & \\
$\mu \mathrm{g} \mathrm{DNA} / m g$ DW & 4 & 1827.9 & 56.9 & $<0.001$ \\
Error & 601 & 32.1 & & \\
$\mu \mathrm{g} \mathrm{RNA} / m g$ DW & 4 & 4322.3 & 17.9 & $<0.001$ \\
Error & 601 & 241.6 & & \\
\hline
\end{tabular}


TABLE 3. - Summary of the results of the one-way analysis of variance (ANOVA) for each of the species (Sardina pilchardus, Engraulis encrasicolus, Atherina presbyter and Paralichthys orbignyanus), showing the significance of the factors (tissues). DF: degrees of freedom and MS: mean square.

\begin{tabular}{|c|c|c|c|c|c|c|c|c|c|c|c|c|}
\hline & \multicolumn{4}{|c|}{ RNA/DNA } & \multicolumn{4}{|c|}{$\mu \mathrm{g}$ DNA/mg DW } & \multirow[b]{2}{*}{ DF } & \multicolumn{3}{|c|}{$\mu \mathrm{g}$ RNA/mg DW } \\
\hline & DF & MS & $\mathrm{F}$ & $\mathrm{p}$ & DF & M S & $\mathrm{F}$ & $\mathrm{p}$ & & MS & $\mathrm{F}$ & $\mathrm{p}$ \\
\hline S. pilchardus & & & & & & & & & & & & \\
\hline $\begin{array}{l}\text { Tissues } \\
\text { Error } \\
\text { E. encrasicolus }\end{array}$ & $\begin{array}{c}4 \\
276\end{array}$ & $\begin{array}{c}245.8 \\
5.8\end{array}$ & 42.3 & $<0.001$ & $\begin{array}{c}4 \\
227\end{array}$ & $\begin{array}{c}633.8 \\
14.1\end{array}$ & 45.1 & $<0.001$ & $\begin{array}{c}4 \\
227\end{array}$ & $\begin{array}{l}4056.1 \\
294.2\end{array}$ & 13.8 & $<0.001$ \\
\hline $\begin{array}{l}\text { Tissues } \\
\text { Error } \\
\text { A. presbyter }\end{array}$ & $\begin{array}{c}4 \\
157\end{array}$ & $\begin{array}{l}72.6 \\
1.0\end{array}$ & 71.5 & $<0.001$ & $\begin{array}{c}4 \\
131\end{array}$ & $\begin{array}{l}1704.8 \\
21.6\end{array}$ & 78.9 & $<0.001$ & $\begin{array}{c}4 \\
131\end{array}$ & $\begin{array}{c}3655.2 \\
131.3\end{array}$ & 27.8 & $<0.001$ \\
\hline $\begin{array}{l}\text { Tissues } \\
\text { Error } \\
\text { P. orbignyanus }\end{array}$ & $\begin{array}{c}4 \\
41\end{array}$ & $\begin{array}{l}80.5 \\
47.0\end{array}$ & 1.7 & 0.17 & $\begin{array}{c}4 \\
41\end{array}$ & $\begin{array}{c}224.3 \\
7.1\end{array}$ & 31.7 & $<0.001$ & $\begin{array}{c}4 \\
41\end{array}$ & $\begin{array}{l}80.5 \\
47.0\end{array}$ & 1.7 & 0.17 \\
\hline $\begin{array}{l}\text { Tissues } \\
\text { Error }\end{array}$ & $\begin{array}{c}4 \\
187\end{array}$ & $\begin{array}{l}160.4 \\
7.3\end{array}$ & 21.9 & $<0.001$ & $\begin{array}{c}4 \\
187\end{array}$ & $\begin{array}{l}105.9 \\
9.6\end{array}$ & 11.1 & $<0.001$ & $\begin{array}{c}4 \\
187\end{array}$ & $\begin{array}{l}383.4 \\
77.1\end{array}$ & 5.0 & $<0.001$ \\
\hline
\end{tabular}

for the head region and the highest for gut (except for A. presbyter gut). The head showed significantly lower RNA:DNA ratios than muscle and gut in all species and also lower than body in S. pilchardus, E. encrasicolus and A. presbyter (see Fig. 2 for the post-hoc differences between tissues).

Higher concentrations of DNA/mg DW were found in the head region than in muscle or gut $(\mathrm{p}<0.001)$, while $\mathrm{RNA} / \mathrm{mg}$ was not significantly different from head and muscle (Figs. 1 and 2). It is also interesting to point out that DNA concentrations in the head region were of the same order of magnitude as those of RNA, resulting in similar RNA:DNA indices (near 1-2) for the head region in all four studied species. Concentrations of DNA were slightly higher in gut than in muscle (except in Paralichthys orbignyanus), but concentrations of RNA were significantly higher in Sardina pilchardus and Engraulis encrasicolus $(\mathrm{p}<0.001$ ), showing the highest RNA:DNA values for this part of the body.

The higher RNA:DNA rates of muscle than head were also evident when flexion and postflexion larvae of Sardina pilchardus and Engraulis encrasicolus were considered separately, but for Paralichthys orbignyanus this difference was significant just for the preflexion larvae (Fig. 3). Head RNA:DNA ratios were not significantly different between developmental stages for any of the three species, while muscle showed significantly higher values in post-flexion larvae of $S$. pilchardus and E. encrasicolus than in early stages $(\mathrm{p}<0.001)$, and no significant differences were found between the two stages in P. orbignyanus (Fig. 3). Although as development advances the absolute amount of DNA or RNA per body section increases (reflect-
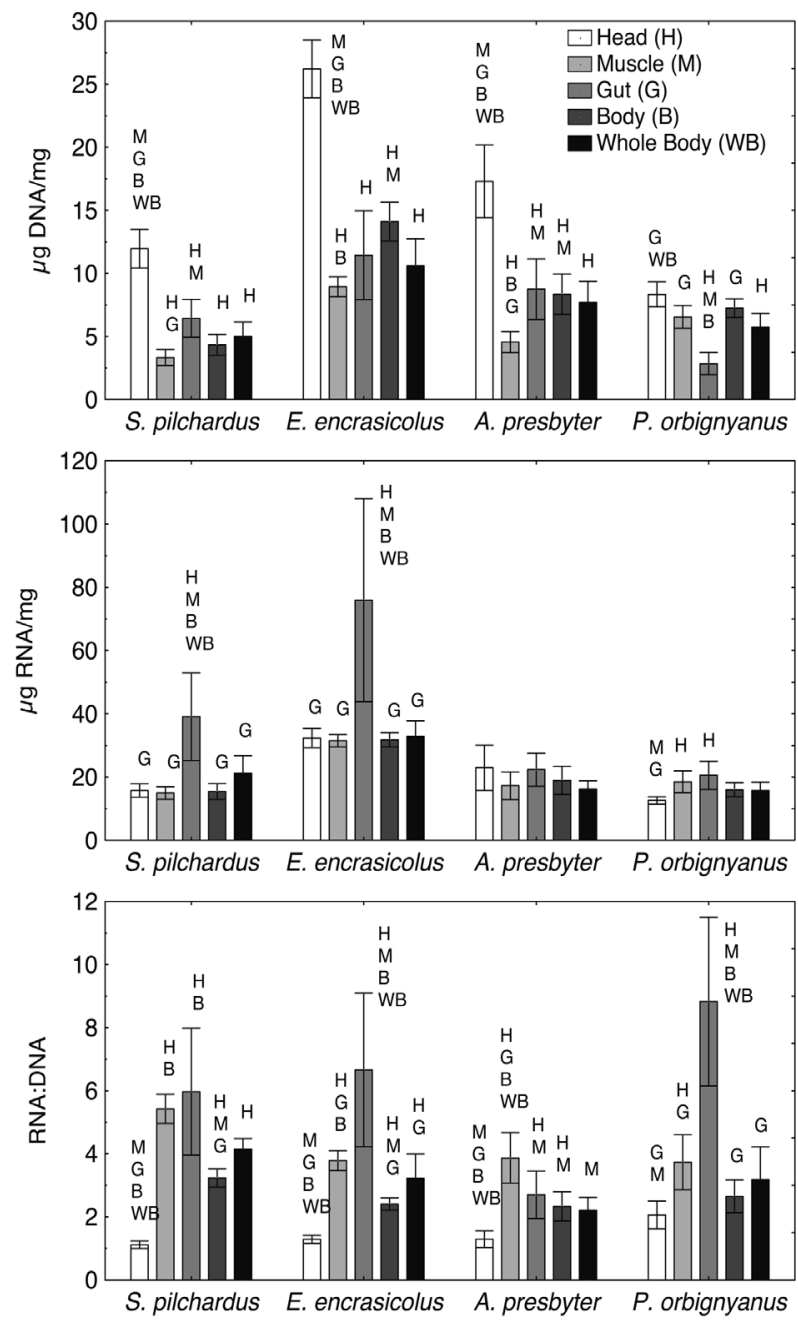

FIG. 2. - Mean values and 95\% confidence intervals of DNA and RNA concentration $(\mu \mathrm{g} / \mathrm{mg} \mathrm{DW})$ and RNA:DNA ratios in the head, muscle, gut, body and whole body tissues of Sardina pilchardus, Engraulis encrasicolus, Atherina presbyter and Paralichthys orbignyanus. Different letters indicate significant differences $(\mathrm{p}<0.001)$ among tissues, after one way ANOVA followed by posthoc Tukey's (HSD) test. 
ing growth), the tendency is not evident when these values are standardised as a function of larval dry weight, with a non-significant decreasing trend in DNA/DW with development and fairly similar concentrations of RNA/DW between the two stages (Fig. 3 upper graph).

The analysis of eyes and the cephalic region without eyes (performed in post-flexion Sardina pilchardus and Atherina presbyter larvae) did not show significant differences in RNA:DNA. Both DNA and RNA per mg of dry weight of eyes showed high concentrations in contrast with the rest of the head (Fig. 4) were noteworthy.

We also analysed the anterior (Muscle 1) and posterior (Muscle 2) sections of the tail in postflexion larvae, and found significant differences in RNA:DNA ratios, with higher values in the anterior section for Sardina pilchardus and Engraulis encrasicolus larvae, while for Paralichthys orbignyanus no differences were evident (Fig. 5).
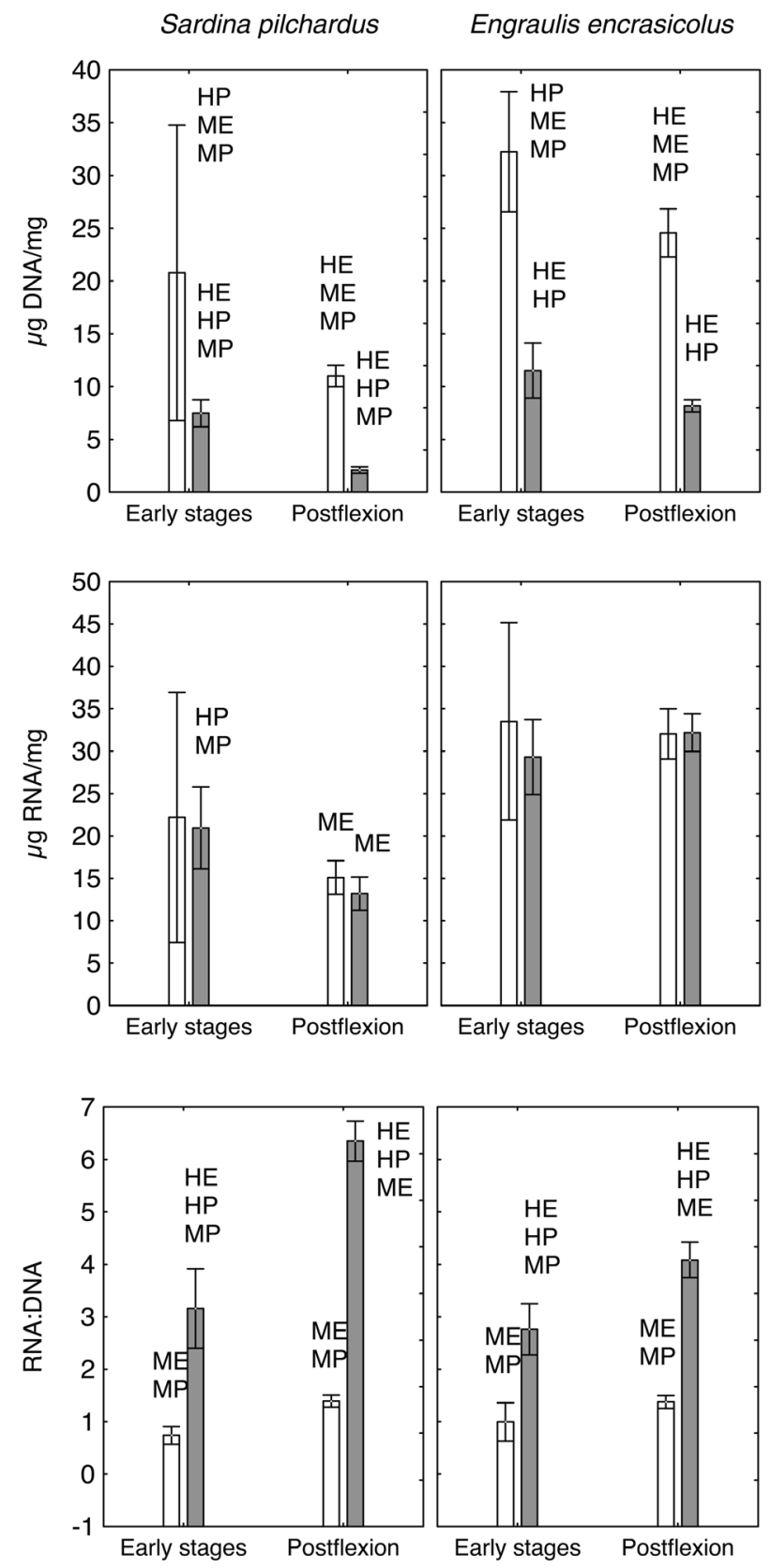

Engraulis encrasicolus
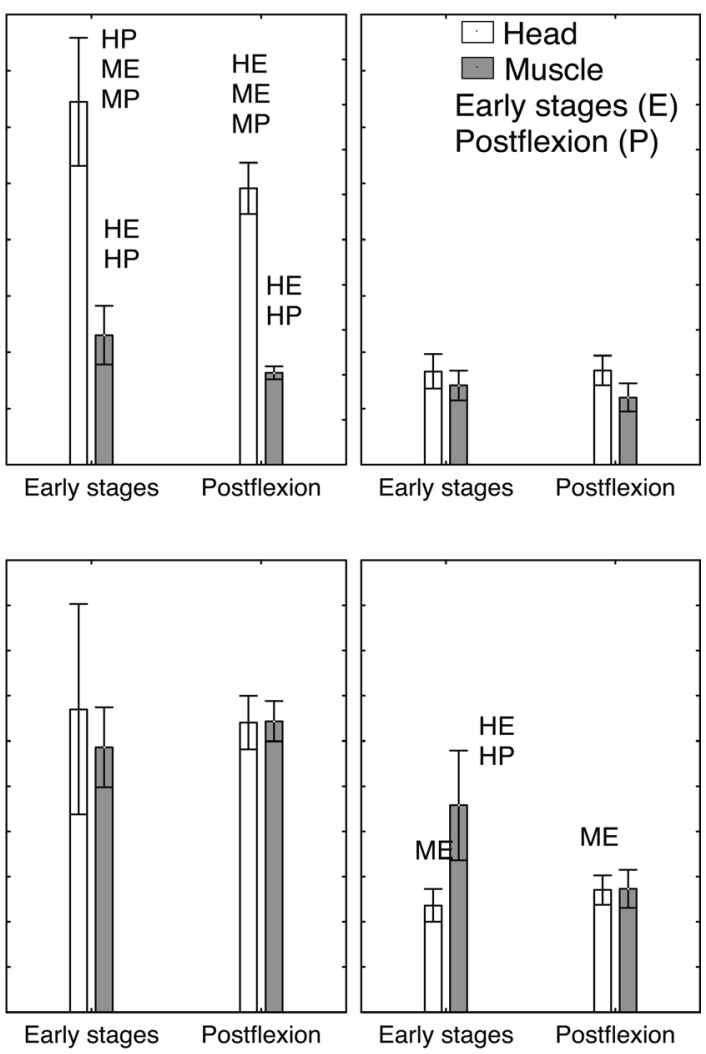

Paralichthys orbignyanus

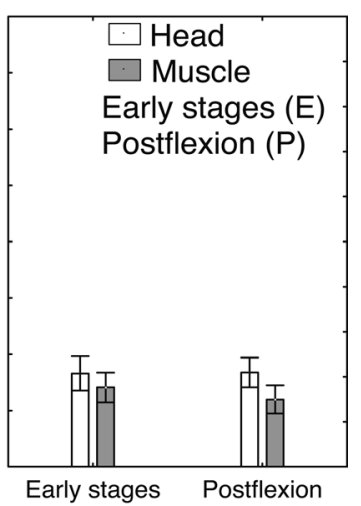

Early stages Postflexion
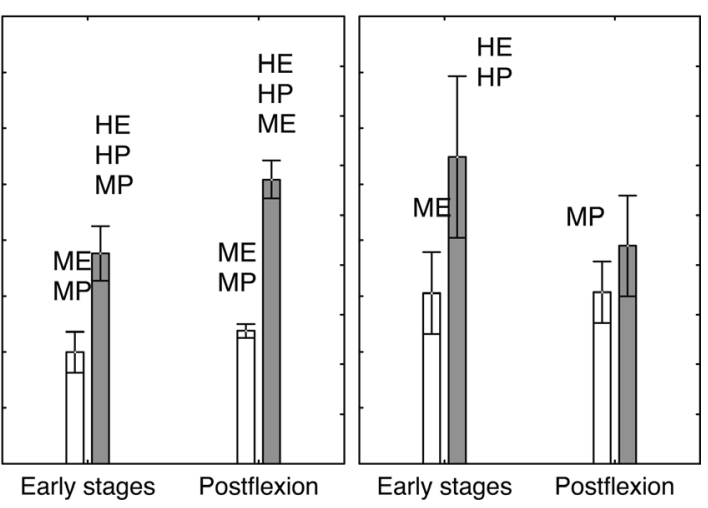

FIG. 3. - Mean values and 95\% confidence intervals of DNA and RNA concentration ( $\mu \mathrm{g} / \mathrm{mg} \mathrm{DW})$ and RNA:DNA ratios in head and muscle tissues for early stages and post-flexion larvae of Sardina pilchardus, Engraulis encrasicolus and Paralichthys orbignyanus. Different letters indicate significant differences $(\mathrm{p}<0.001)$ among tissues, after multifactorial ANOVA followed by post-hoc Tukey's (HSD) test. 

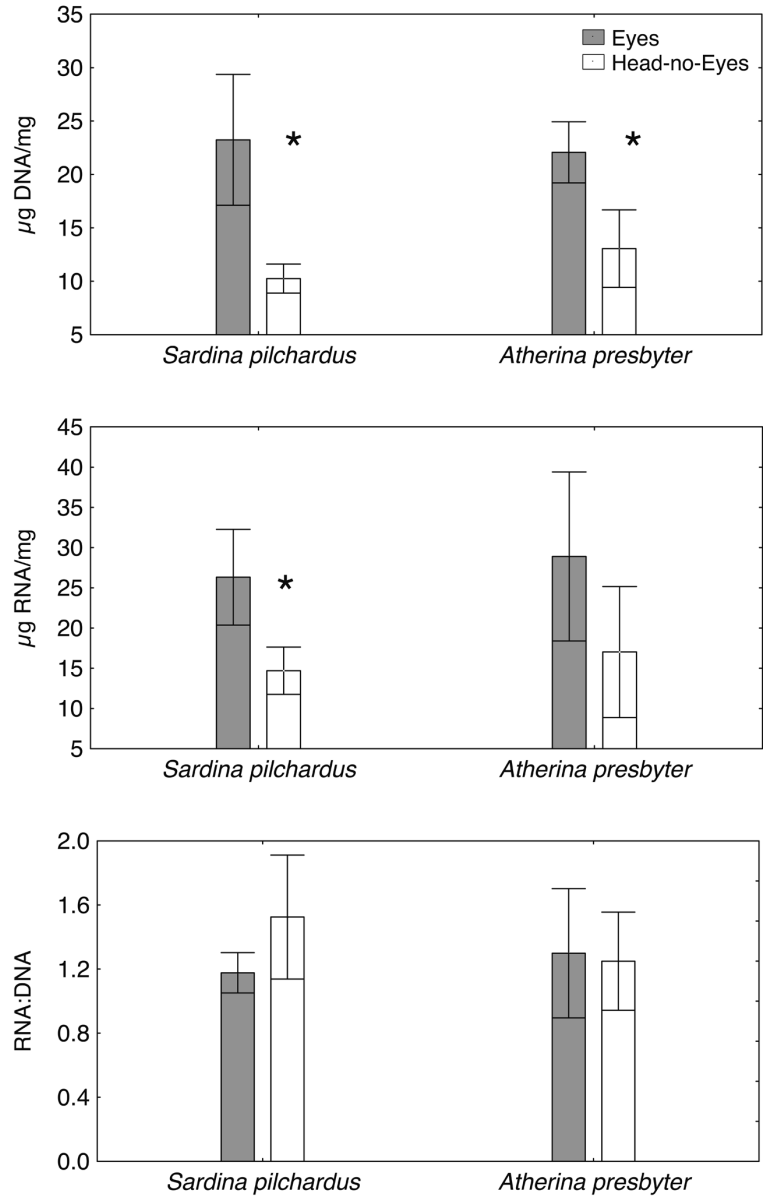

FIG. 4. - Mean values and 95\% confidence intervals of DNA and RNA concentration ( $\mu \mathrm{g} / \mathrm{mg}$ DW) and RNA:DNA ratios in eyes and head without eyes of Sardina pilchardus and Atherina presbyter. Significant differences $(\mathrm{p}<0.001)$ between body parts for each species obtained after $t$ test indicated by *

In order to determine which part of the body best reflects starvation, we compared a set of larvae subject to starvation with well-nourished larvae. Significant differences in RNA:DNA ratios of head and muscle of $19 \mathrm{DAH}$ pre-flexion larvae fed and starved were observed, with a similar increase in both tissues (a factor of 3 in fed larvae). In post-flexion larvae subject to 4-7 days of fast, although all tissues showed lower mean values in fasted larvae, only significant differences between the same tissues were found for muscle (Fig. 6). The percentage of decrease in RNA:DNA index from fed to starved pre-flexion larvae was $70.5 \%$ for head and $64 \%$ for muscle, while for post-flexion stages it was $40 \%$ and $58 \%$, respectively.

Based on the differences found in RNA:DNA among tissues, for each of the four species and developmental stages studied we calculated a conversion factor (c.f.) for body or whole body vs muscle $(\mathrm{B} / \mathrm{M}$ or $\mathrm{WB} / \mathrm{M})$. The conversion factor between body and muscle RNA:DNA was $c a$. 0.6 in both
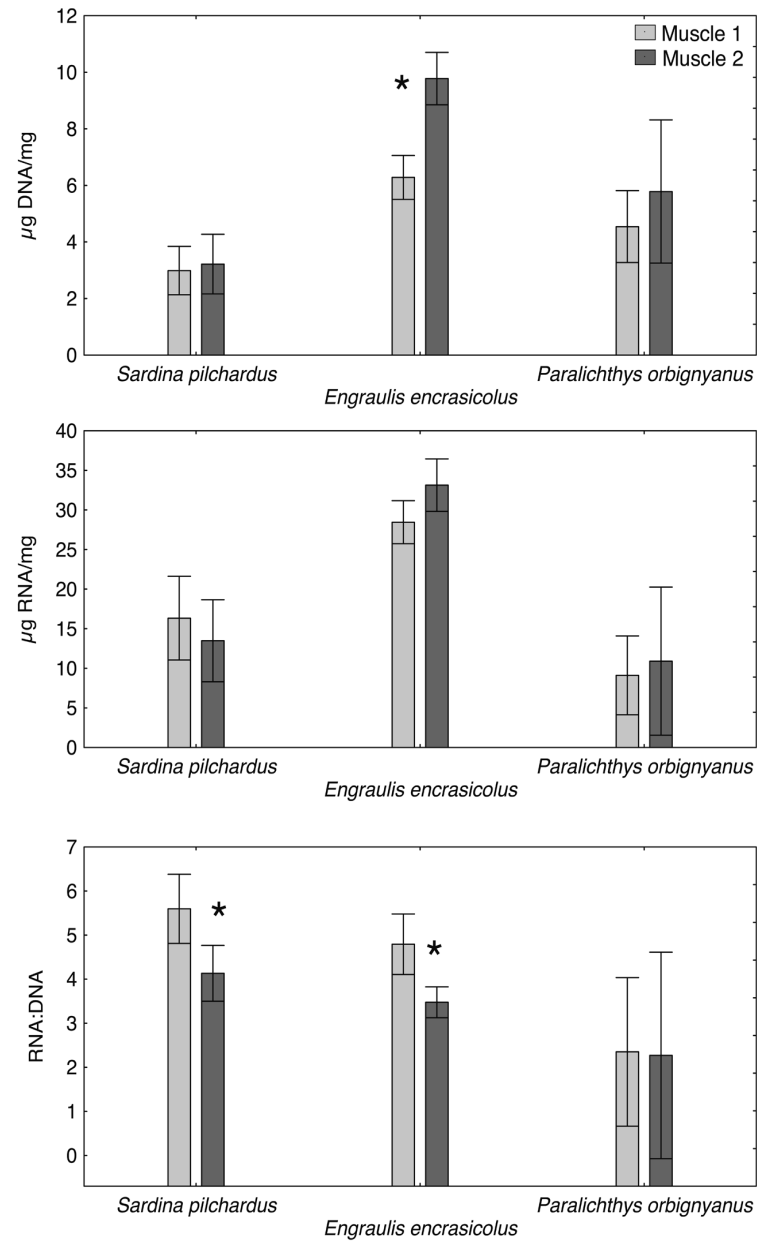

FIG. 5. - Mean values and 95\% confidence intervals of DNA and RNA concentration ( $\mu \mathrm{g} / \mathrm{mg} \mathrm{DW})$ and RNA:DNA ratios in anterior (Muscle 1) and posterior parts (Muscle2) of the tail for Sardina pilchardus, Engraulis encrasicolus and Paralichthys orbignyanus. Significant differences $(\mathrm{p}<0.001)$ between tail sections for each species obtained after $t$ test indicated by*.

flexion and post-flexion Sardina pilchardus and Engraulis encrasicolus and post-flexion Atherina presbyter larvae. In Paralichthys orbignyanus the $\mathrm{B} / \mathrm{M}$ conversion factor increased from 0.65 in preflexion to 0.75 in post-flexion larvae (Table 4 ). As fluorescence readings of guts from pre-flexion larvae were below the detection limit, the conversion factor between whole body and muscle could only be calculated in post-flexion larvae. The conversion factor between whole body and muscle rendered higher values than $\mathrm{B} / \mathrm{M}$, except in A. presbyter, for which values were similar.

\section{DISCUSSION}

The most outstanding result of this work was the fact that the RNA:DNA ratio in the head was lower than in muscle. This was observed for the dif- 

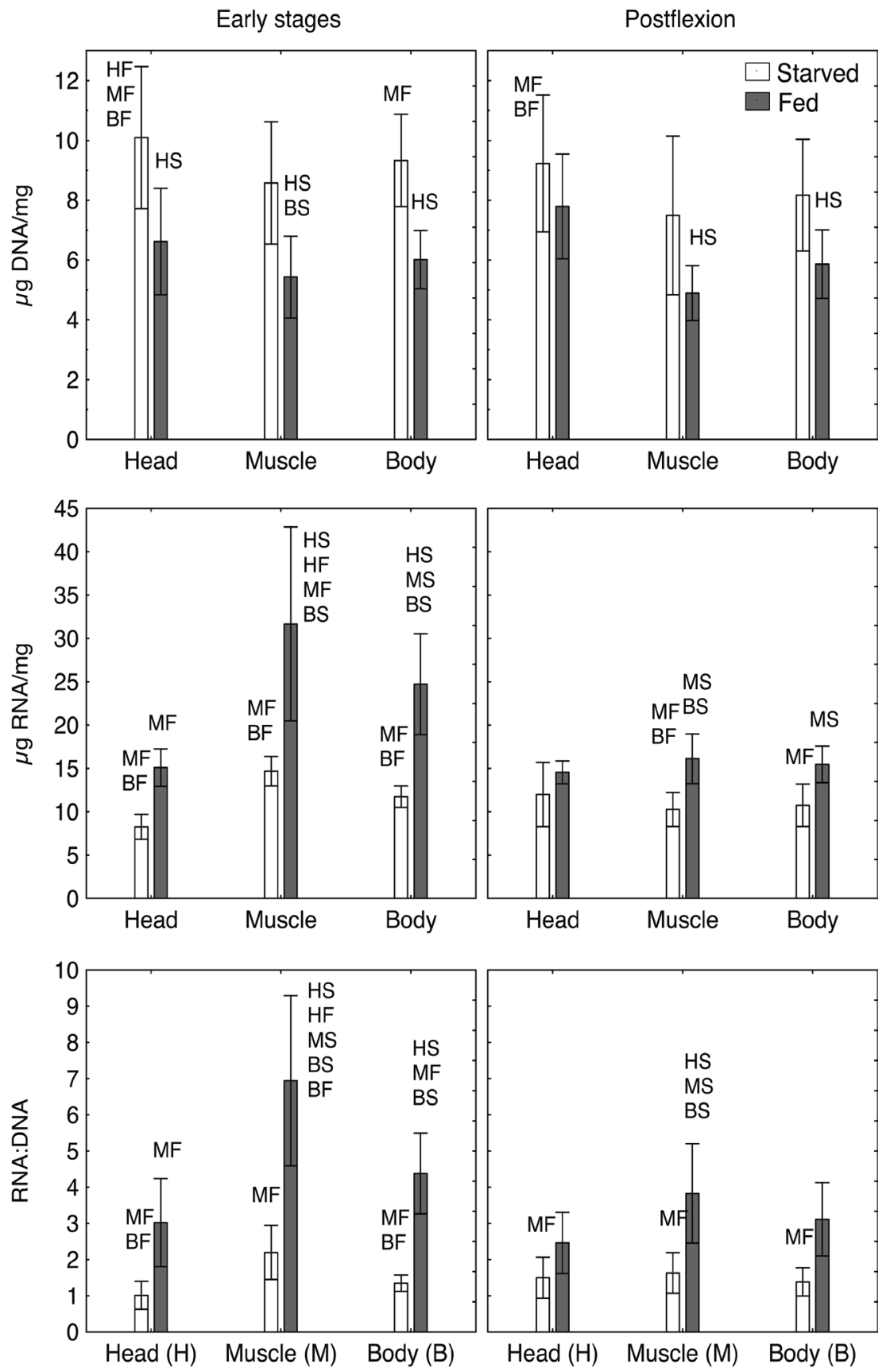

FIG. 6. - Mean values and 95\% confidence intervals of DNA and RNA concentration ( $\mu \mathrm{g} / \mathrm{mg} \mathrm{DW})$ and RNA:DNA ratios in head, muscle and body tissues for pre-flexion and post-flexion larvae of Paralichthys orbignyanus from feeding treatments (fed and starved). Different letters indicate significant differences $(\mathrm{p}<0.001)$ among tissues and feeding condition for every developmental stage after multifactorial ANOVA followed by post-hoc Tukey's (HSD) test.

TABLE 4. - RNA:DNA conversion factor (c.f.) for body/muscle (B/M), or whole body/muscle (WB/M) for each of the four studied species. Body $=$ Head + Muscle; Whole body $=$ Head + Muscle + Gut.

\begin{tabular}{|c|c|c|c|c|c|c|}
\hline & \multicolumn{2}{|c|}{ Early stages } & \multicolumn{4}{|c|}{ Post-flexion } \\
\hline & c.f. B/M & $\mathrm{n}$ & c.f. B/M & $\mathrm{n}$ & c.f. WB/M & $\mathrm{n}$ \\
\hline Sardina pilchardus & 0.58 & 17 & 0.59 & 46 & 0.66 & 17 \\
\hline Engraulis encrasicolus & 0.64 & 9 & 0.63 & 36 & 0.79 & 7 \\
\hline Atherina presbyter & - & - & 0.60 & 10 & 0.57 & 8 \\
\hline Paralichthys orbignyanus & 0.65 & 25 & 0.75 & 28 & 1.05 & 16 \\
\hline All species & 0.62 & 51 & 0.64 & 120 & 0.77 & 48 \\
\hline
\end{tabular}


ferent species and for the different developmental stages analysed. In spite of the balancing effect of the combination of data from all species and all size classes, this pattern was also significant, stressing the consistency of these differences. Moreover, the fact that RNA:DNA ratios of larvae collected in the sea showed the same pattern as reared larvae also confirmed this common behaviour.

The lower RNA:DNA ratio in the head than in muscle could indicate that the head had lower growth rates than muscle tissues. The lower growth rate in the head has been related to a lower protein synthesis, or to lower cytochrome oxidase activity (Goolish and Adelman, 1987; Houlihan and Laurent, 1987). However, the similar RNA concentration in the head and in muscle observed in the present study does not point to a lower protein synthesis. The low RNA:DNA values found in the head were actually due to the higher DNA concentrations, probably resulting from the presence of a large number of small cells in this part of the body. Opposite results were observed for the gut section (the highest RNA:DNA values) which, based on its higher RNA concentrations, seems to have a higher potential to synthesise proteins than the head and even than muscle. We do not believe that the gut content was responsible for these higher RNA concentrations, because the two species that showed the highest RNA concentrations, Sardina pilchardus and Engraulis encrasicolus, had an almost negligible amount of food in their guts, while RNA concentrations in Atherina presbyter (which had full guts) were not significantly different from those in other tissues. Our results suggest that the highest RNA:DNA values in gut may be related to the presence of liver and pancreas, which are attached to the gut and appeared together in the analysed homogenate. In adult fish, in which the liver and viscera can be dissected, higher RNA concentrations in liver have been found than in muscle (Bulow, 1971; Luquet, 1971), stomach and intestine (Bulow, 1971). Generally, the liver is an organ of high protein synthesis in well-nourished fish (Houlihan et al., 1986) and it has been reported that RNA:DNA ratios can rise more than in white muscle during accelerated metabolic activity (Bulow, 1987). Supporting this idea, Mukherjee and Jana (2007) found in three adult fish species that RNA:DNA values were higher in liver than in muscle. Moreover, Luquet (1971), working with adult trout, reported higher RNA:DNA in liver than in muscle and the lowest values for the head and other tissues (fins, axial skeleton and skin). The same pattern was observed by Fukuda (1993) while studying differential tissue contents of glycogen in Pacific herring (Clupea pallasi) larvae. Glycogen concentration in head tissues was constant and low during development, trunk concentration increased but was intermediate, and the highest values were found for the viscera. This fact was associated with muscle development during hypertrophy and liver energy storage to help avoid starvation.

The analysis of eyes and the cephalic region without eyes performed in post-flexion Sardina pilchardus and Atherina presbyter larvae did not show significant differences in RNA:DNA. Thus, the analysis of specimens with lost eyes is probably not a serious issue. We also found significant differences in RNA:DNA ratios when analysing different muscle tail sections in post-flexion Sardina pilchardus and Engraulis encrasicolus larvae. Supporting our findings, Bulow (1987) reported in adult catfish Heteropneustes fossilis higher DNA concentrations in the tail musculature than the trunk region, and explained this fact as being a consequence of the small size of tail muscle cells. Therefore, according to these evidences, RNA:DNA ratios obtained from subsamples of larvae should be used with caution.

The lack of differences in RNA:DNA ratios between developmental stages for the head (in any of the species) contrasts with the higher values observed in post-flexion stages for muscle, which is mainly due to the decreasing muscle DNA concentrations and the similar RNA concentrations in this latter stage. According to Malzahn et al. (2003) for larval coregonid fish, the decreasing trend in DNA concentration during development is due to a switch from a higher proportion of hyperplasia in small fish to a higher proportion of hypertrophy in larger fish. The decline of DNA concentration during development was also indicated by Buckley et al., (1999) and Fonseca et al (2006). In addition, in agreement with our results, Tanaka et al. (2007) found for bluefin tuna larvae an increase in the total amount of DNA and RNA as development advanced, but the standardised RNA and protein contents per weight unit (mg/mg WW) showed steady concentrations during development. In the same study, the DNA content per unit weight began to decrease and maintained a low level from 21 DAH. At this time, the proteinDNA ratio showed a rapid increase associated with 
the rapid somatic growth in both length and weight, suggesting cell enlargement (Tanaka et al., 2007). Johnson and Hall (2004) also showed a decrease in hyperplasia in muscle cells in larvae larger than 20 $\mathrm{mm}$ in clupeid species, such as herring.

Several studies have shown that starved individuals tend to have lower growth rates, higher mortality rates, and lower RNA:DNA than fed controls (Dahlhoff, 2004). Changes in protein synthetic capacity either measured directly or by means of an RNA:DNA index respond to changes in food availability in the order of days, illustrating the power of this technique for assaying organisms in a rapidly changing natural environment (McNamara et al., 1999). Nevertheless, the effect of selected tissue in detecting starved organisms in the field has not yet been completely clarified. In previous studies, Bulow (1971) found for adult bluegills (Lepomis machrochirus) that RNA:DNA ratios of liver are more sensitive to changes in nutritional status than other tissues (i.e. stomach, intestine, anterior and posterior trunk muscle). In addition, Fukuda et al., 2001 working with reared Paralichthys olivaceus juveniles also demonstrated the existence of a relationship between liver RNA:DNA values and food ration.

The starvation experiment with Paralichthys orbignyanus demonstrates that the early larval phases are more susceptible to nutritional stress than postflexion larvae, probably due to the higher reserves available in the latter pre-metamorphic stage. We found that both head and muscle tissues exhibit lower RNA:DNA ratios for the starving pre-flexion larvae, while only muscle was significantly different for the post-flexion larvae. Lower RNA:DNA ratios for starved larvae were due to both a decrease in RNA concentration and an increase in DNA concentration. Bergeron (1997) indicated that this relative increase in DNA concentration occurs because dry weight of starved larvae decreases while DNA remains stable, which seems to be the case also in our study.

The larger decrease in RNA concentration from fed to starved larvae observed in pre-flexion compared with post-flexion Paralichthys orbignyanus could be related to a lower protein synthetic capacity caused by ribosomal degradation in these pre-flexion larvae, as is reported to occur in early stages of other species (Rosenlund et al., 1984; Houlihan et al., 1986). Some studies indicate that brain metabolic activity remains constant regardless of changes in environmental food quality or quantity (Yang and Somero, 1993; Kawall et al.,
2002). Other studies indicate that, under unfavourable conditions, brain protein synthesis is unaffected (Smith et al., 1996) or much less affected than in white muscle (Lewis et al., 2007). It has been reported that white muscle is the amino acid and energy store for other tissues during starvation periods (Love, 1970; Houlihan et al., 1986). The present results for post-flexion larvae, in which differences between starved and fed conditions were detected in muscle, but not in the head, may be explained because fasted larvae may obtain energy by mobilising proteins from muscle, as suggested previously in other starving fish larvae based on histological or cell-cycle analysis (Catalán and Olivar, 2002; Catalán et al., 2007). This may allow some brain metabolic activity to be preserved during starvation periods.

A decrease in activity due to low food availability directly impacts on swimming performance, causing a decline in the ability of an individual to escape from predators or capture prey, and is therefore related to survival. Conversely, brain metabolic activity, while low, is conserved during starvation, presumably to allow the individual to survive until conditions are better for active movement and growth. Therefore, muscle tissue seems to be better than head tissue to reflect starvation. However, as previous major calibration experiments described in the literature to determine starvation and growth rates based on RNA:DNA ratio responses of fish larvae analysed the entire larvae, caution is needed when RNA:DNA ratios obtained without using the entire larvae are compared with these studies. For the species studied we propose conversion factors to be applied to the RNA:DNA ratio data in order to classify starving larvae or to calculate growth rate when only different body sections are analysed.

\section{ACKNOWLEDGEMENTS}

The authors would like to thank Marcelo Pájaro, from INIDEP, Argentina for providing Paralichthys orbignyanus larvae. This work was partially funded by the Spanish CTM2004-03510-C02-01/MAR Project, the "Centre de Referència de Recerca i Desenvolupament en Aqüicultura (CRA-CIRIT)" of the "Generalitat de Catalunya" and the Portuguese "Fundação para a Ciência e a Tecnologia" that financed the sabbatical grant to Maria Alexandra Chícharo (SFRH/BSAB/745 /2007), financed by Por- 
tuguese "Fundação para a Ciência e a Tecnologia" and by the Spanish CTM2004-03510-C02-01/MAR Project. M.V. Díaz acknowledges MAEC-AECI Fellowship support from the Agencia Española de Cooperación Internacional.

\section{REFERENCES}

Bailey, K.M., M.F. Canino, J.M. Napp, S.M. Spring and A.L. Brown. - 1995. Contrasting years of prey levels, feeding conditions and mortality of larval walleye pollock Theragra chalcogramma in the western Gulf of Alaska. Mar. Ecol. Prog. Ser., 119: 11-23.

Belchier, M. C. Clemmesen, D. Cortés, A. Doan, A. Folkvord, A. García, A.J. Geffen, H. Høie, A. Johannessen, E. Moksness, H. de Pontual, T. Rámirez, D. Schnack and B. Sveinsbø. - 2004. Recruitment studies: Manual of precision and accuracy of tools. ICES Techniques in Mar. Env. Sci., 33: 1-35.

Berdalet, E. and Q. Dortch. - 1991. New double staining technique from the measurement of RNA and DNA measurement in marine phytoplankton. Mar. Ecol. Prog. Ser., 73: 295-305.

Berdalet, E., C. Roldán, M.P. Olivar and K. Lysnes. - 2005. Quantifying RNA and DNA in planktonic organisms with SYBR Green II and nucleases. Part A. Optimisation of the assay. Sci. Mar., 69(1): 1-16

Bergeron, J.P. - 1997. Nucleic acids in ichthyoplankton ecology: a review, with emphasis on recent advances for new perspectives. J. Fish. Biol., 51(A): 284-302.

Buckley, L.J. - 1984. RNA/DNA ratio: an index of larval fish growth in the sea. Mar. Biol., 80: 291-298.

Buckley, L.J., E. Caldarone and T.L. Ong. - 1999. RNA-DNA ratio and other nucleic acid-based indicators for growth and condition of marine fishes. Hydrobiology, 401: 265-277.

Buckley, L.J., E.M. Caldarone and C. Clemmesen. - 2008. Multispecies larval fish growth model based on temperature and fluorometrically derived RNA/DNA ratios: results from a metaanalysis. Mar. Ecol. Progr. Ser., 371: 221-232. doi:10.3354/ meps07648

Bulow, F.J. - 1970. RNA-DNA ratios as indicators of recent growth rates of a fish. J. Fish. Res. Board Can., 27: 2343-2349.

Bulow, F.J. - 1971. Selection of suitable tissues for use in RNA/ DNA ratio technique of assessing recent growth rate of a fish. Iowa State College J. Sci., 46: 71-78.

Bulow, F.J. - 1987. RNA-DNA ratios as indicators of growth in fish: A review. In: R.C. Summerfelt and E. Gordon (eds.), The age and growth of fish, pp. 45-64. The Iowa State University Press, Ames, Iowa.

Caldarone, E.M. - 2005. Estimating growth in haddock larvae Melanogrammus aeglefinus from RNA: DNA ratios and water temperature. Mar. Ecol. Prog. Ser., 293: 241-252.

Caldarone, E.M. and L.J. Buckley. - 1991. Quantification of DNA and RNA in crude tissues extracts by flow injection analysis. Anal. Biochem., 199: 137-141.

Caldarone, E.M., M. Wagner, J. St. Onge-Burns and L.J. Buckley. 2001. Protocol and guide for estimating nucleic acids in larval fish using a fluorescence microplate reader. Northeast Fish. Sci.Cent. Ref. Doc. 01-11; 22 p. Available from: National Marine Fisheries Service, 166 Water Street, Woods Hole, MA 02543-1026.

Caldarone, E.M., C.M. Clemmesen, E. Berdalet, T.J. Miller, A. Folkvord, G. J. Holt, M.P. Olivar and I.M. Suthers. - 2006 Intercalibration of four spectrofluorometric protocols for measuring RNA/DNA ratios in larval and juvenile fish. Limnol. Oceanogr. Methods, 4: 153-163.

Catalán, I.A. and M.P. Olivar. - 2002. Quantification of muscle condition using digital image analysis in Dicentrarchus labrax larvae, and relationship with survival. J. Mar. Biol. Ass. U.K., 82(4): 649-654.

Catalán, I.A., E. Berdalet, M.P. Olivar and C. Roldán. - 2007. Response of muscle-based biochemical condition indices to short-term variations in food availability in post-flexion reared sea bass (Dicentrarchus labrax L.) larvae. J. Fish Biol., 70(2): 391-405.

Chícharo, M.A., L.M. Chícharo, L. Valdez, E. Lopez-Jamar and P.
Re. - 1998. Estimation of starvation and diel variation of the RNA/DNA ratios in field-caught Sardina pilchardus larvae off the north of Spain. Mar. Ecol. Prog. Ser., 164: 273-283.

Chícharo, M.A., A. Amaral, P. Morais and L. Chícharo. - 2007. Effect of sex on ratios and concentrations of DNA and RNA in three marine species. Mar. Ecol. Prog. Ser. 332: 241-245.

Clemmesen, C. -1994 . The effect of food availability, age or size on the RNA/DNA ratio of individually measured herring larvae: laboratory calibration. Mar. Biol., 118: 377-382.

Dahlhoff, E.P. - 2004. Biochemical indicators of stress and metabolism: Applications for Marine Ecological Studies. Annu. Rev. Physiol., 66: 183-207.

Ferron, A. and W.C. Leggett. - 1994. An appraisal of condition measures for marine fish larvae. Adv. Mar. Biol., 30: 217-303.

Folkvord, A., L. Ystanes and E. Moksness. - 1996. RNA:DNA ratios and growth of herring (Clupea harengus) larvae reared in mesocosms. Mar. Biol., 126: 591-602.

Fonseca, V.F., C. Vinagre and H.N. Cabral. - 2006. Growth variability of juvenile soles Solea solea and Solea senegalensis, and comparison with RNA:DNA ratios in the Tagus estuary, Portugal. J. Fish. Biol., 68: 1551-1562.

Fukuda, M. - 1993. Changes in the glycogen content of Pacific herring, Clupea pallasi, during metamorphosis and the subsequent juvenile stage. Bull. Nansei Natl. Fish. Res. Inst., 26: 107-111.

Fukuda, M., H. Sako, T. Shigeta and R. Shibata. - 2001. Relationship between growth and biochemical indices in laboratory reared juvenile Japanese flounder and its application to wild fish. Mar. Biol., 138: 47-55.

Goolish, E.M., M.G. Barron and I.R. Adelman. - 1984. Thermoacclimatory response of nucleic acid and protein content of carp muscle tissue: influence of growth rate and relationship to glycine uptake by scales. Can. J. Zool., 62: 2164-2170.

Goolish, E.M. and I.R. Adelman. - 1987. Tissue-specific cytochrome oxidase activity in largemouth bass: the metabolic costs of feeding and growth. Physiol. Zool., 69(4): 454-464.

Grémare, A. and G. Vétion. - 1994. Comparison of several spectrofluorimetric methods for measuring RNA and DNA concentrations in the deposit-feeding bivalve Abra ovata. Comp. Biochem. Physiol., 107B(2): 297-308.

Houlihan, D., D.N. McMillan and P. Laurent. - 1986. Growth rates, protein synthesis and protein degradation rates in rainbow trout: effects of body size. Physiol. Zool., 59: 482-493.

Houlihan, D. and P. Laurent. - 1987. Effects of exercise training on the performance, Growth and Protein Turnover of Rainbow trout (Salmo gairdneri). Can. J. Fish. Aquat. Sci., 44: 1614-1621.

Ikeda, T., F. Sano, A. Yamaguchi and T. Matsuishi. - 2007. RNA:DNA ratios of calanoid copepods from the epipelagic through abyssopelagic zones of the North Pacific Ocean. Aquat. Biol., 1: 99-108.

Johnson, I.A. and T.E. Hall. - 2004. Mechanisms of Muscle Development and Responses to Temperature Change in Fish Larvae. Am. Fish. Soc. Symp., 40: 85-116.

Kawall H.G., J.J. Torres, B.D. Sidell and G.N. Somero. - 2002. Metabolic cold adaptation in Antarctic fishes: evidence from enzymatic activities of brain. Mar. Biol., 140: 279-86.

Lewis, J.M. and W.R. Driedzic. - 2007. Tissue specific changes in protein synthesis associated with seasonal metabolic depression and recovery in the north temperate labrid, Tautogolabrus adspersus. Am. J. Physiol. Regul. Integr. Comp. Physiol., 293(1): 474-481. DOI: 10.1152/ajpregu.00594.2006

Love R.M. - 1970. The chemical biology of fishes, Vol.1. Academic press, New York.

Lowery, M.S. and G.N. Somero. - 1990. Starvation effects on protein synthesis in red and white muscle of the barred sand bass Paralabras nebulifer. Physiol. Zool., 63: 630-648.

Luquet, P. - 1971. Etude du développement chez la truite. Evolution de la teneur en acides nucléiques dans diverses fractions corporelles. Ann. Biol. Anim. Biochim. Biophys., 11: 657-668.

Malzahn, A.M., C. Clemmesen and H. Rosenthal. - 2003 Temperature effects on growth and nucleic acids in laboratory-reared larval coregonid fish. Mar. Ecol. Prog. Ser., 259: 285-293.

McNamara P.T., E.M. Caldarone and L.J. Buckley. - 1999. RNA/ DNA ratio and expression of $18 \mathrm{~S}$ ribosomal RNA, actin and myosin heavy chain messenger RNAs in starved and fed larval Atlantic cod (Gadus morhua). Mar. Biol., 135: 123-132.

Mukherjee, S. and B.B. Jana. - 2007. Water quality affects SDH ac- 
182 - M.P. OLIVAR et al.

tivity, protein content and RNA:DNA ratios in fish (Catla catla, Labeo rohita and Oreochromis mossambicus) raised in ponds of a sewage-fed fish farm. Aquaculture, 262: 105-119.

O'Connell, C.P. 1980.- Percentage of starving northern anchovy, Engraulis mordax, larvae in the sea estimated by histological methods Fish. Bull., 78(2): 475-489.

Ramírez, T., D. Cortés and A. García. - 2001 Growth of north Alboran Sea sardine larvae estimated by otolith microstructure, nucleic acids and protein content. J. Fish. Biol., 59: 403-415.

Robinson, S.M.C. and D.M. Ware. - 1988. Ontogenetic development of growth rates of larval Pacific herring, Clupea harengus pallasi, measured with RNA-DNA ratios in the Strait of Georgia. British Columbia. Can. J. Fish. Aquat. Sci., 45: 1422-1429.

Rooker, J.R. and G.J. Holt. - 1996. Application of RNA:DNA ratios to evaluate the condition and growth of larval and juvenile red drum (Sciaenops ocellatus). Mar. Freshw. Res., 47: 283-290.

Rosenlund, G., B. Lund, K. Sanders, O.R. Braekkan and A. von der Decaen. - 1984. Muscle protein synthesis in vitro (Pollachius virens) correlated to growth and daily energy intake. Comp. Biochem. Physiol., 77B: 7-13.

Smith, R.W., D.F. Houlihan, G.E. Nilsson and J.G. Brechin. - 1996. Tissue-specific changes in protein synthesis rates in vivo during anoxia in crucian carp. Am. J. Physiol. Regul. Integr. Comp. Physiol., 271(4): 897-904.
Suthers, I.M., J.J. Cleary, S.C. Battaglene and R. Evans. - 1996. Relative RNA contents as a measure of condition in larval and juvenile fish. Mar. Freswater Res., 47: 301-307.

Sykes, A., P. Domingues and J.P. Andrade. - 2004. Nucleic acid derived indices or instantaneous growth rate as tools to determine different nutritional condition in cuttlefish (Sepia officinalis, Linnaeus 1758) hatchlings. J. Shellfish Res., 23(2): 585-591.

Tanaka, Y., W.S. Gwak, M. Tanaka, Y. Sawada, T. Okada, S. Miyashita and H. Kumai. - 2007. Ontogenetic changes in RNA, DNA and protein contents of laboratory-reared Pacific bluefin tuna Thunnus orientalis. Fish. Sci., 73: 378-384.

Theilacker, G.H. - 1986. Starvation-induced mortality of young sea-caught jack mackerel, Trachurus symmetricus, determined with histological and morphological methods. Fish. Bull., 84: $1-17$.

Yang T.H., and G.N.Somero. - 1993. Effects of feeding and food deprivation on oxygen consumption, muscle protein concentration, and activities of energy metabolism enzymes in muscle and brain of shallow- (Scorpaena guttata) and deep- (Sebastelobus alascanus) living Scorpaenid fishes. J. Exp. Biol., 181: 213-230.

Received October 16, 2008. Accepted May 25, 2009.

Published online October 5, 2009. 